\title{
Physiological quality and gene expression related to heat-resistant proteins at different stages of development of maize seeds
}

\author{
T. Andrade ${ }^{1}$, E.V.R. Von Pinho ${ }^{1}$, R.G. Von Pinho' ${ }^{1}$ G.E. Oliveira ${ }^{2}$, \\ V. Andrade ${ }^{1}$ and J.S. Fernandes ${ }^{1}$ \\ ${ }^{1}$ Departamento de Agricultura, Universidade Federal de Lavras, Lavras, MG, Brasil \\ ${ }^{2}$ Departamento de Biologia, Universidade Federal de Lavras, Lavras, MG, Brasil \\ Corresponding author: T. Andrade \\ E-mail: thaisandradeagro@gmail.com
}

Genet. Mol. Res. 12 (3): 3630-3642 (2013)

Received December 6, 2012

Accepted August 14, 2013

Published September 13, 2013

DOI http://dx.doi.org/10.4238/2013.September.13.7

\begin{abstract}
We quantified and characterized the expression of heatresistant proteins during seed development of maize lines with distinct levels of tolerance to high drying temperature. A corn field was planted for multiplication of seeds of different lines, two tolerant and two nontolerant to high drying temperatures. Harvest of the seeds was carried out at various stages of development and they were then subjected to tests of moisture content, germination, first count of germination, accelerated aging, and cold test. The seeds were stored in a freezer for later analysis of expression of heat-resistant proteins by means of real-time PCR, electrophoresis, and spectrophotometry. We observed that heat-resistant proteins are expressed in a differential manner in seeds from different lines and at different stages of development. The expression of heatresistant proteins was earlier in lines tolerant to high drying temperatures. Greater germination and vigor values was found for seeds collected at the last stage of development.
\end{abstract}

Key words: Zea mays; qRT-PCR; LEA proteins 


\section{INTRODUCTION}

In recent years, there has been an increase in the demand for high-quality maize seeds, mainly with the commercialization of genetically modified seed products in Brazil, which requires high-quality standards from the producing companies and must be associated with profitable production systems. It is noteworthy that in 2010, 219 thousand tons of maize seeds were sold in the country since the crop has a high rate of seed use, i.e., 84\% (ABRASEM - Associação Brasileira de Sementes e Mudas, 2011). In this new scenario, investments in technology are a priority in companies because seed production is a specialized activity and care must be given to all stages of the production process.

One of the important stages in the seed production process is the harvest, which must be carried out at the right time for the purpose of reducing possible qualitative and quantitative losses as much as possible. Delay in harvest contributes substantially to seed deterioration, since seeds are subject to adverse conditions in the field. In Brazil, the ear corn harvesting system has been prioritized with regard to the possibility of earlier harvest and lower incidence of mechanical damage to seed that normally occurs during combining, as well as the optimization of production (Roveri José et al., 2004). On the basis of some research studies, the harvest of maize seeds in the milk line 3 (ML3) stage of development has been proposed, when $50 \%$ of the endosperm is hard. In this stage, most of the seeds of different cultivars have high moisture content, which requires artificial drying, a process that may reduce seed quality, resulting in low germination and vigor. Nevertheless, this reduction depends on the expression of genes associated with the trait of tolerance to high drying temperatures, which varies according to the genotype (Huang et al., 2012).

In seed develop, there are changes in gene expression, leading to the formation of proteins that have distinct traits and functions. The increase in heat-resistant proteins, among other mechanisms, seems to be involved in the acquisition and maintenance of desiccation tolerance, providing protection against the consequences of moisture loss at different hydration levels (Hundertmark and Hincha, 2008).

Understanding the expression of these genes is essential for the development of processing methods that ensure the production and commercialization of high-quality seeds. Thus, the aim of this study was to evaluate the physiological quality of seeds from maize lines with distinct levels of tolerance to high drying temperatures and to quantify and characterize the expression of heat-resistant proteins during seed development.

\section{MATERIAL AND METHODS}

The study was conducted in the experimental area and in the Central Seed Laboratory of the Departamento de Agricultura of Universidade Federal de Lavras (UFLA), in Lavras, MG, Brazil. A field was planted for the multiplication of seeds from four lines provided by the company Geneseeds Ltda. Among the lines used, two were previously classified as tolerant to high drying temperature (lines 30 and 91) and two as non-tolerant (lines 43 and 57) (Roveri-José et al., 2004).

For each line, ten $10-\mathrm{m}$ rows were planted with between-row spacing of $0.8 \mathrm{~m}$ and 7 plants $/ \mathrm{m}$, in four blocks. Crop treatments were made according to those recommended for the crop.

Upon flowering, plants were manually self-pollinated. During seed development, solidification of the endosperm was monitored by means of the ML, and seed harvest was carried 
out at various stages of development according to the classification of Hunter et al. (1991): ML1 (100\% liquid endosperm) with this stage being reached at 19 days after pollination for lines 30, 57, 91, and at 21 days for line 43; ML2 (25\% solid endosperm); ML3 (50\% solid endosperm); ML4 (75\% solid endosperm), and ML5 (100\% solid endosperm). Soon after harvest, the seeds were evaluated for quality by means of germination, vigor, and moisture content tests. Some of these seeds were stored in a deep freezer at $-84^{\circ} \mathrm{C}$, for analysis of the expression of heat-resistant proteins.

The moisture content of the seed was determined by the oven method at $105^{\circ} \mathrm{C}$ for $24 \mathrm{~h}$, using two replicates of each treatment. The germination test was conducted with four replicates of 50 seeds, sowed between germitest paper towels moistened with distilled water in the ratio of $2.5 \mathrm{~mL} / \mathrm{g}$ paper. The germination chamber was set at $25^{\circ} \mathrm{C}$ and the evaluations of normal seedlings were performed on two counts, 4 and 7 days after sowing. These tests were conducted according to the Seed Analysis Rules [Regras para Análise de Sementes (RAS)] (Brasil, 2009). Carried out together with the germination test, first counting was performed on the fourth day after sowing, computing the percentage of seedlings that had at least two seminal roots and an above ground part at least $2 \mathrm{~cm}$ in length.

The artificial aging test was performed in "gerbox", where seeds were suspended on a screen inside the box, containing $40 \mathrm{~mL}$ water. Seeds remained were incubated for $96 \mathrm{~h}$ at a temperature of $41^{\circ} \mathrm{C}$ according to the method proposed by Marcos Filho (1994), then was performed germination test as described above. The cold test without soil was performed according to Dias and Barros (1995).

For quantification of heat-resistant proteins, 11 embryos of each treatment were ground for $1 \mathrm{~min}$ and $15 \mathrm{~s}$ in a mortar over ice in the presence of buffer solution ( $50 \mathrm{mM}$ Tris- $\mathrm{HCl}, \mathrm{pH} 7.5$, $500 \mathrm{mM} \mathrm{NaCl}, 5 \mathrm{mM} \mathrm{MgCl} 2,1 \mathrm{mM} \mathrm{PMSF}$ ) at a proportion of 1:10 (weight of material:volume of extraction buffer), and transferred to $1500-\mu \mathrm{L}$ microtubes. The homogenized products were centrifuged at $14,000 \mathrm{rpm}$ for $30 \mathrm{~min}$, at $4^{\circ} \mathrm{C}$, and the supernatant was incubated in a water bath at $85^{\circ} \mathrm{C}$ for $15 \mathrm{~min}$ and once more centrifuged. The supernatant was poured off into microtubes and the pellet was discarded. The microtubes with the supernatant were placed in a boiling water bath for $5 \mathrm{~min}$, and electrophoresis was then carried out. Determination of proteins was also carried out according to the Bradford method (Bradford, 1976) using bovine serum albumin for constructing the calibration curve. Five milliliters of the staining solution and $100 \mu \mathrm{L}$ of the prepared sample were used. Protein content was expressed as $\mu \mathrm{g} / \mathrm{g}$ seed.

For assessment of expression of heat-resistant proteins by real-time PCR, RNA was extracted from the seeds collected at different stages of development. The seeds were macerated in the presence of liquid nitrogen with addition of the reagent Pure Link RNA Plant ${ }^{\mathbb{B}}$ (Invitrogen), following manufacturer specifications. The integrity and purity of the RNA were evaluated at all stages by denaturing agarose gel electrophoresis (stained with SYBR ${ }^{\circledR}$ Green II, Applied Biosystems) and using an electrophotometer (NanoVue).

After extraction of nucleic acids, the samples were treated with DNAse Free to avoid any contamination with DNA. Accordingly, the DNAse Turbo Free ${ }^{\circledR}$ AMBIOM kit was used following the protocol recommended by the manufacturer. After the extraction and purification process, mRNA was used as a template for cDNA synthesis. The High Capacity cDNA Reverse Transcription $\mathrm{cDNA}^{\circledR}$ kit from Applied Biosystems was used, according to the protocol recommended by the manufacturer. The efficiency of the cDNA synthesis was proven by conventional PCR. 
The sequences of the target genes were obtained by searching the database of the maize genome sequences in GenBank. On the basis of these sequences, the primers were designed using the Primer Express 3.0 software (Applied Biosystems). The sequences of the primers are shown in Table 1. The ubiquitin and ADH genes were used as endogenous controls (Scholdberg et al., 2009).

\begin{tabular}{ll}
\multicolumn{1}{c}{ Table 1. Primers used in qRT-PCR analysis. } \\
\hline Gene & Sequence $\left(5^{\prime} \rightarrow 3^{\prime}\right)$ \\
\hline Late embryogenesis abundant protein D34 & F: CCGGCTCCACGCAGAAC \\
Late embryogenesis abundant protein & R: TATAGGCGTAGCCCTGCATGA \\
Heat shock protein 1 & F: TGCAGCCTCCTAGTGCTTGTAC \\
Ubiquitin & F: CATGAGAGGACACTGGGATTG \\
Alcohol dehydrogenase (ADH) & R: TCTGGAAGCCCAACCAAAAGG \\
& F: AAGGCCAAGATCCAGGACAA \\
\hline
\end{tabular}

$\mathrm{F}=$ sequence of the forward primer; $\mathrm{R}=$ sequence of the reverse primer.

The 7500 Real-time PCR System (Applied Biosystems) was used for real-time PCR analyses. qRT-PCR was carried out using the SYBR ${ }^{\circledR}$ Green PCR Master Mix (Applied Biosystems), and the cDNA samples were synthesized from the extracted RNA. The thermal conditions of the reaction were $2 \mathrm{~min}$ at $50^{\circ} \mathrm{C}, 10 \mathrm{~min}$ at $95^{\circ} \mathrm{C}$, followed by 40 cycles of $15 \mathrm{~s}$ at $95^{\circ} \mathrm{C}$ and $1 \mathrm{~min}$ at $60^{\circ} \mathrm{C}$, and completed with $15 \mathrm{~s}$ at $95^{\circ} \mathrm{C}$. The data were collected and stored in the program 7500 Fast Software (Version 2.1). For each reaction, $1.0 \mu \mathrm{L}$ cDNA, $0.2 \mu \mathrm{L}$ of each primer, and 5.0 $\mu \mathrm{L}$ Master Mix SYBR Green UDG with ROX (Invitrogen) were used, for a final volume of $10.0 \mu \mathrm{L} / \mathrm{sample}$. Negative controls, consisting of water, and endogenous controls were included in all analyses. All reactions were performed in triplicate.

Data collection was performed with the v.2.0.1 software of the 7500 Real-Time PCR System (Applied Biosystems). The comparative cycle threshold (Ct) method was used for relative quantification, where the $\mathrm{Ct}$ of the samples were normalized using the $\mathrm{Ct}$ of the endogenous controls. For that purpose, a prior validation experiment was performed so as to verify that the amplification efficiencies of the target and endogenous genes were similar and near $100 \%$. The standard curves for the efficiency test for the genes under study were generated from the following dilutions: 1:5, 1:25, 1:125, 1:625, and 1:3125. This procedure also allowed the definition of the best cDNA solution to be used in each reaction, which was 1:5.

The samples corresponding to the seeds collected at the ML1 stage were considered as being calibration samples since they were expected to show less expression of the genes studied. For quantification of gene expression by the real-time PCR, the values obtained corresponding to the mRNA levels of the samples were compared to the values of the mRNA levels of the controls. After obtaining the raw data, they were analyzed using the 7500 SDS software (Version 2.0.1). To calculate the level of expression of the genes of interest, the following were considered: $\mathrm{Ct}$ (exponential increase of the PCR product) of the target gene and endogenous control, $\Delta \mathrm{Ct}=\mathrm{Ct}$ (sample) - $\mathrm{Ct}$ (endogenous control), and the $\Delta \Delta \mathrm{Ct}=\Delta \mathrm{Ct}$ (sample) - $\Delta \mathrm{Ct}$ (calibrator). The level of expression was then calculated by the formula: $\mathrm{RQ}=2^{-\Delta \Delta C t}$.

In the tests performed for evaluation of physiological quality of the seeds, a randomized block experimental design was used in a 4 x 5-factorial arrangement (four lines and five stages of development) with four replications for the germination and first count of germination tests and a $3 \times 5$-factorial arrangement (three lines and five stages of development) with 
four replications for the artificial aging tests and cold test. Data were submitted to analysis of variance and the mean values were compared by the Scott Knott grouping test at the 5\% level. Analyses were carried out in the R 2.14.1 (2011) statistical program.

\section{RESULTS}

According to the results of analysis of variance, there was significant interaction between lines and stages of development for all the variables analyzed. The moisture contents of maize seeds of lines 43, 30, 57, and 91 are shown in Table 2.

Table 2. Moisture contents of maize seeds of the 43, 30, 57, and 91 lines, collected at different stages of development.

\begin{tabular}{lcccc}
\hline Stages & \multicolumn{3}{c}{ Line } \\
\cline { 2 - 5 } & 43 & 30 & 57 & 91 \\
\hline ML1 & 60.97 & 63.72 & 68.29 & 66.34 \\
ML2 & 54.27 & 51.53 & 50.75 & 52.91 \\
ML3 & 45.60 & 43.99 & 42.95 & 46.52 \\
ML4 & 39.45 & 36.28 & 35.95 & 37.74 \\
ML5 & 26.04 & 22.30 & 28.35 & 26.32 \\
\hline
\end{tabular}

According to the results of the first count of germination test, the quality of the seeds collected at the ML5 stage of development was greater than that of the seeds collected at the other stages, for all lines (Table 3). In the ML1 and ML2 stages, normal seedlings were not observed for any of the lines, which was also observed in the germination test. There was a low germination percentage in seeds collected at the ML3 stage. The germination percentages (Table 4) of the seeds collected at the ML5 stage were higher than those collected at the other stages of development, except for those collected at the ML4 stage of lines 30 and 91.

Table 3. Mean values (\%) of normal seedlings in the first count of germination test of maize seeds of the 43 , 30,57 , and 91 lines collected at different stages of development.

\begin{tabular}{|c|c|c|c|c|c|}
\hline \multirow[t]{2}{*}{ Line } & \multicolumn{5}{|c|}{ Stages } \\
\hline & ML1 & ML2 & ML3 & ML4 & ML5 \\
\hline 43 & $0^{\mathrm{Ac}}$ & $0^{\mathrm{Ac}}$ & $10^{\mathrm{Ab}}$ & $28^{\mathrm{Bb}}$ & $91^{\mathrm{Aa}}$ \\
\hline 30 & $0^{\mathrm{Ac}}$ & $0^{\mathrm{Ac}}$ & $3^{\mathrm{Bc}}$ & $35^{\mathrm{Bb}}$ & $96^{\mathrm{Aa}}$ \\
\hline 57 & $0^{\mathrm{Ac}}$ & $0^{\mathrm{Ac}}$ & $1^{\mathrm{Bc}}$ & $12^{\mathrm{Cb}}$ & $70^{\mathrm{Ca}}$ \\
\hline 91 & $0^{\mathrm{Ac}}$ & $0^{\mathrm{Ac}}$ & $1^{\mathrm{Bc}}$ & $58^{\mathrm{Ab}}$ & $79^{\mathrm{Ba}}$ \\
\hline
\end{tabular}

Mean values with the same capital letters in the column and small letters in the line do not differ among themselves by the Scott-Knott test at the $5 \%$ level of probability.

\begin{tabular}{|c|c|c|c|c|c|}
\hline \multirow[t]{2}{*}{ Line } & \multicolumn{5}{|c|}{ Stages } \\
\hline & ML1 & ML2 & ML3 & ML4 & ML5 \\
\hline 43 & $0^{\text {Ad }}$ & $0^{\text {Ad }}$ & $42^{\mathrm{Ac}}$ & $68^{\mathrm{Bb}}$ & $99^{\mathrm{Aa}}$ \\
\hline 30 & $1^{\mathrm{Ac}}$ & $0^{\mathrm{Ac}}$ & $13^{\mathrm{cb}}$ & $98^{\mathrm{Aa}}$ & $99^{\mathrm{Aa}}$ \\
\hline 57 & $2^{\mathrm{Ac}}$ & $2^{\mathrm{Ac}}$ & $1^{\mathrm{Dc}}$ & $22^{\mathrm{cb}}$ & $93^{\mathrm{Ba}}$ \\
\hline 91 & $0^{\mathrm{Ac}}$ & $3^{\mathrm{Ac}}$ & $31^{\mathrm{Bb}}$ & $97^{\text {Аа }}$ & $100^{\mathrm{Aa}}$ \\
\hline
\end{tabular}

Mean values with the same capital letters in the column and small letters in the line do not differ among themselves by the Scott-Knott test at the $5 \%$ level of probability. 
The artificial aging tests (Table 5) and cold test (Table 6) were conducted only in seed lines 30,57 , and 91 due to the small quantity of seeds produced from line 43 . According to the results of the artificial aging test (Table 5), the seeds collected at the ML5 stage had greater vigor than those from the other stages. Also, the seeds collected at the ML1 stage did not germinate after artificial aging.

\begin{tabular}{|c|c|c|c|c|c|}
\hline \multirow[t]{2}{*}{ Line } & \multicolumn{5}{|c|}{ Stages } \\
\hline & ML1 & ML2 & ML3 & ML4 & ML5 \\
\hline 30 & $0^{\mathrm{Ad}}$ & $0^{\mathrm{Bd}}$ & $21^{\mathrm{Cc}}$ & $71^{\mathrm{Bb}}$ & $98^{\mathrm{Aa}}$ \\
\hline 57 & $0^{\text {Ad }}$ & $7^{\mathrm{Bc}}$ & $31^{\mathrm{Bc}}$ & $86^{\mathrm{Ab}}$ & $97^{\mathrm{Aa}}$ \\
\hline 91 & $0^{\text {Ad }}$ & $27^{\mathrm{Ad}}$ & $51^{\mathrm{Ac}}$ & $69^{\mathrm{Bb}}$ & $98^{\mathrm{Aa}}$ \\
\hline
\end{tabular}

Mean values with the same capital letters in the column and small letters in the line do not differ among themselves by the Scott-Knott test at the $5 \%$ level of probability.

Table 6. Mean values of normal seedlings by the cold test without soil of maize seeds of lines 30, 57, and 91 in different stages of development.

\begin{tabular}{lccccc}
\hline Line & \multicolumn{5}{c}{ Stages } \\
\cline { 2 - 6 } & ML1 & ML2 & ML3 & ML4 & ML5 \\
\hline 30 & $0^{\text {Ad }}$ & $23^{\mathrm{Cc}}$ & $89^{\mathrm{Bb}}$ & $95^{\mathrm{Aa}}$ & $97^{\mathrm{Aa}}$ \\
57 & $0^{\mathrm{Ad}}$ & $36^{\mathrm{Bc}}$ & $34^{\mathrm{Cc}}$ & $76^{\mathrm{Bb}}$ & $99^{\mathrm{Aa}}$ \\
91 & $0^{\mathrm{Ad}}$ & $83^{\mathrm{Ab}}$ & $94^{\mathrm{Aa}}$ & $97^{\mathrm{Aa}}$ & $100^{\mathrm{Aa}}$ \\
\hline
\end{tabular}

Mean values with the same capital letters in the column and small letters in the line do not differ among themselves by the Scott-Knott test at the $5 \%$ level of probability.

In the results obtained in the cold test (Table 6), the vigor of seeds collected at the ML5 stage was greater compared to seeds collected at the other stages for line 57 . As for line 30 , the vigor of the seeds collected at the ML5 stage did not differ from those collected at the ML4 stage, while for line 91, there was no difference in vigor between the seeds collected at the different stages of development ML3, ML4, and ML5.

In relation to evaluation of expression of heat-resistant proteins by electrophoresis, for line 43, previously classified as non-tolerant to desiccation, the greatest expression of heatresistant proteins occurred in the ML5 stage of development (Figure 1A). In seeds collected at the earlier stages, there was less expression of these heat-resistant proteins.

For line 30, considered as tolerant to desiccation, expression of the heat-resistant proteins was observed already as of the ML2 stage (Figure 1B). For line 57, also classified as non-tolerant to desiccation, the greatest expression of heat-resistant proteins was in the ML4 and ML5 stages, with the latter stage showing higher levels (Figure 1C). Line 91 showed the same result as line 30, where expression of the heat-resistant proteins was observed starting at the ML2 stage (Figure 1D).

For quantification of heat-resistant proteins by spectrophotometry, greater values of these proteins were generally observed in the ML5 stage for all the cultivars analyzed (Figure 2). An increasing quantity of proteins measured by this technique was also observed with seed development stage. 

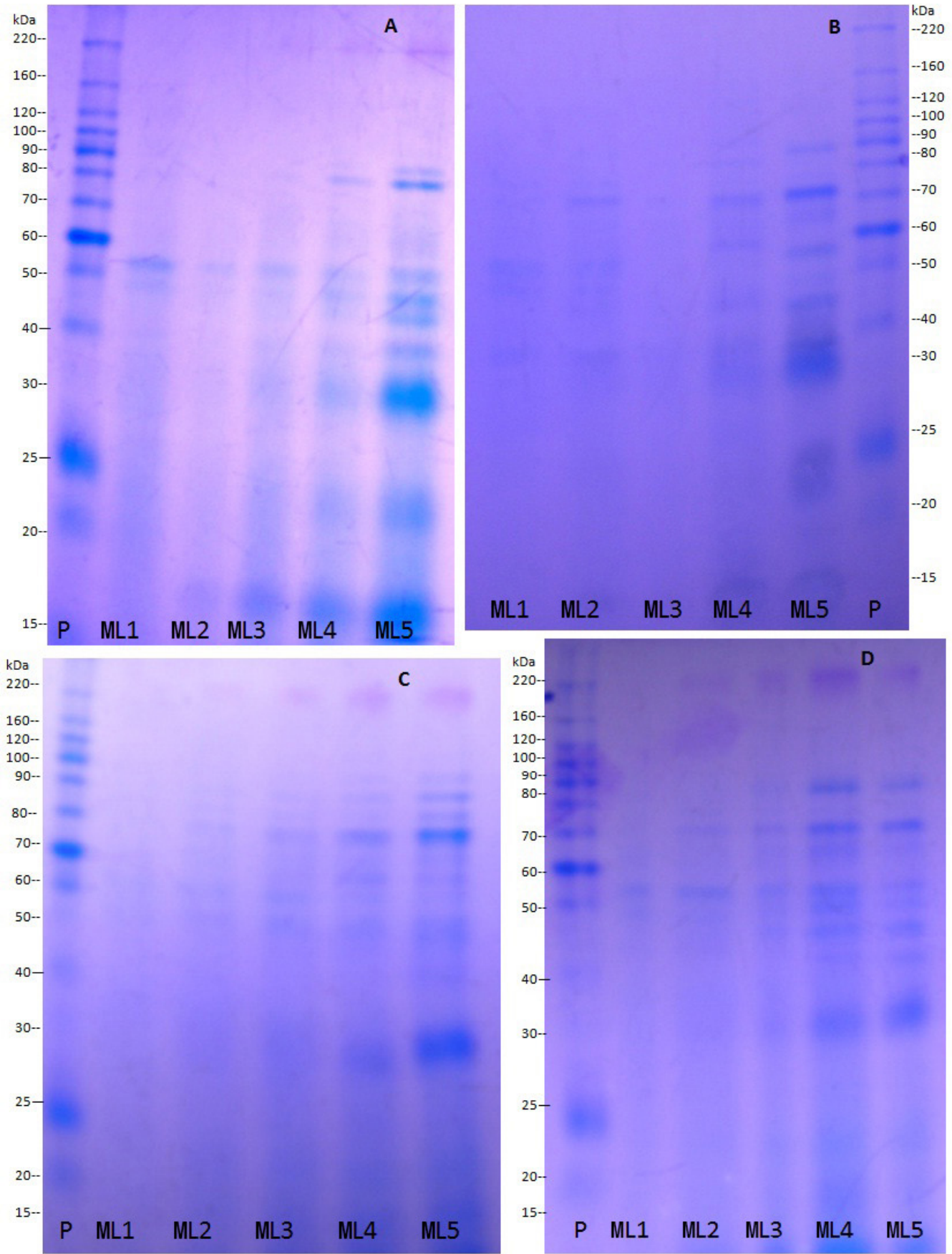

Figure 1. Pattern of heat-resistant proteins of maize seeds collected at different stages of development. Lane $P=$ protein pattern. A. Line 43; B. line 30; C. line 57; D. line 91. 


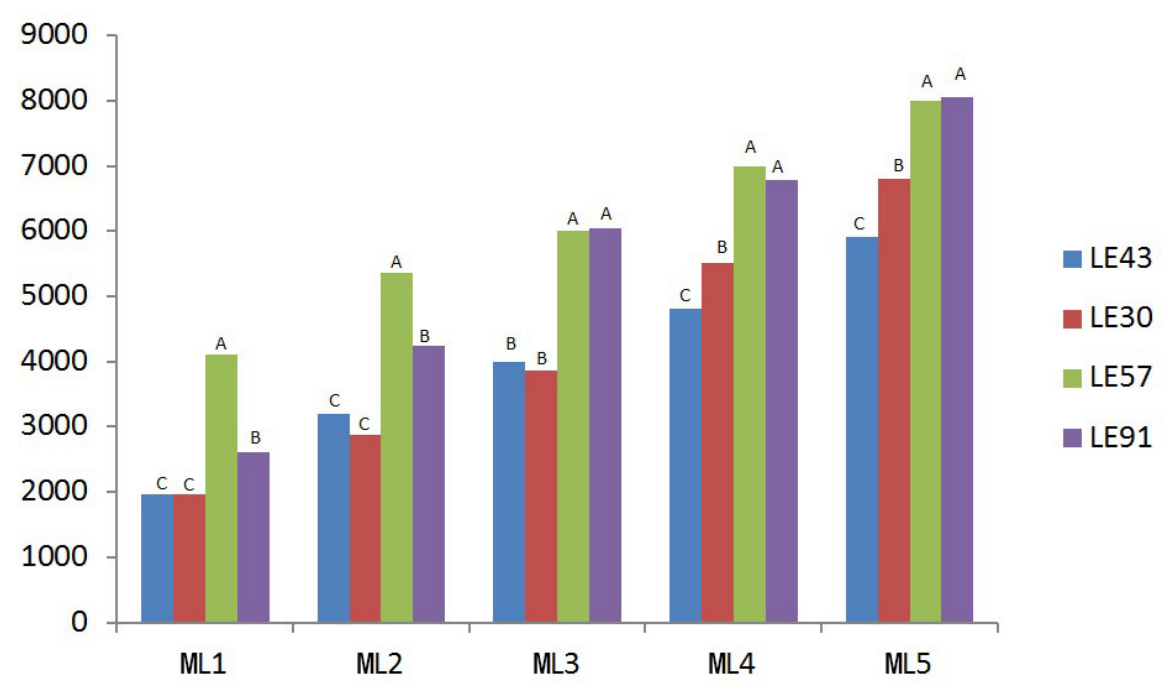

Figure 2. Heat-resistant proteins extracted from maize seeds of lines (LE) 43, 30, 57, and 91, collected at different stages of development.

In general, large variation was observed in the expression of the genes analyzed in seeds of different lines. For line 43 (Figure 3), classified as non-tolerant to high drying temperatures, expression of the HS gene gradually increased in the seeds collected up to the ML3 stage, and decreased in those collected at the ML4 stage and increased again in the ML5 stage, where maximal expression occurred. The same held true for the seeds of line 91 (Figure 4), classified as tolerant to desiccation. The seeds of line 57 (Figure 5), classified as non-tolerant, had the highest expression level for this gene in relation to the other lines, where expression was greatest in the last two stages of seed development. As for the seeds of line 30 (Figure 6), the greatest expression of this gene occurred in the ML4 stage.
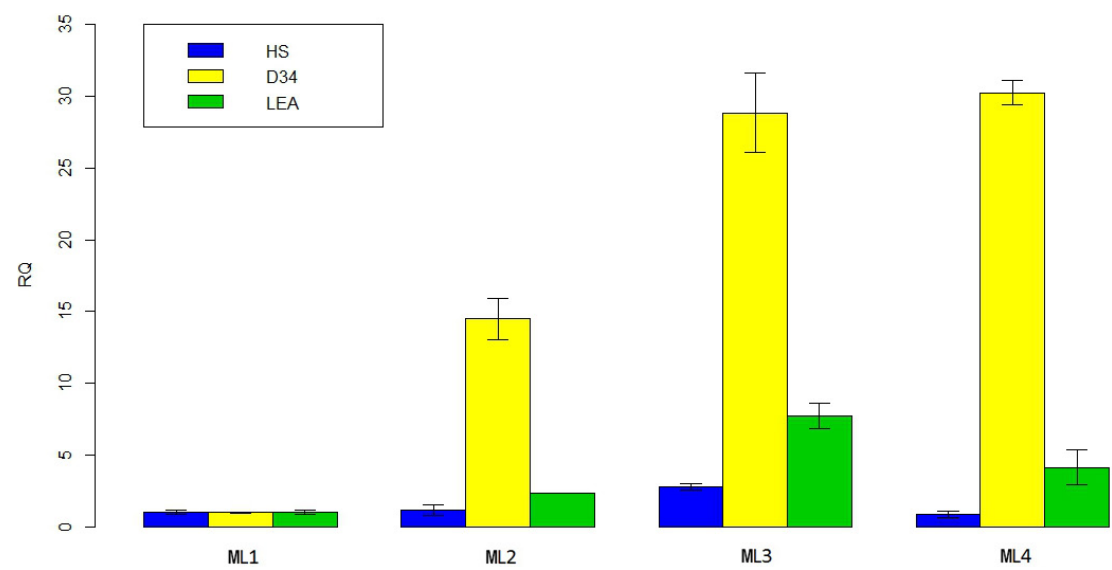

Figure 3. Profile of relative quantitative (RQ) expression of genes D34, HS, and LEA in maize seeds of line 43 collected at different stages of development. 

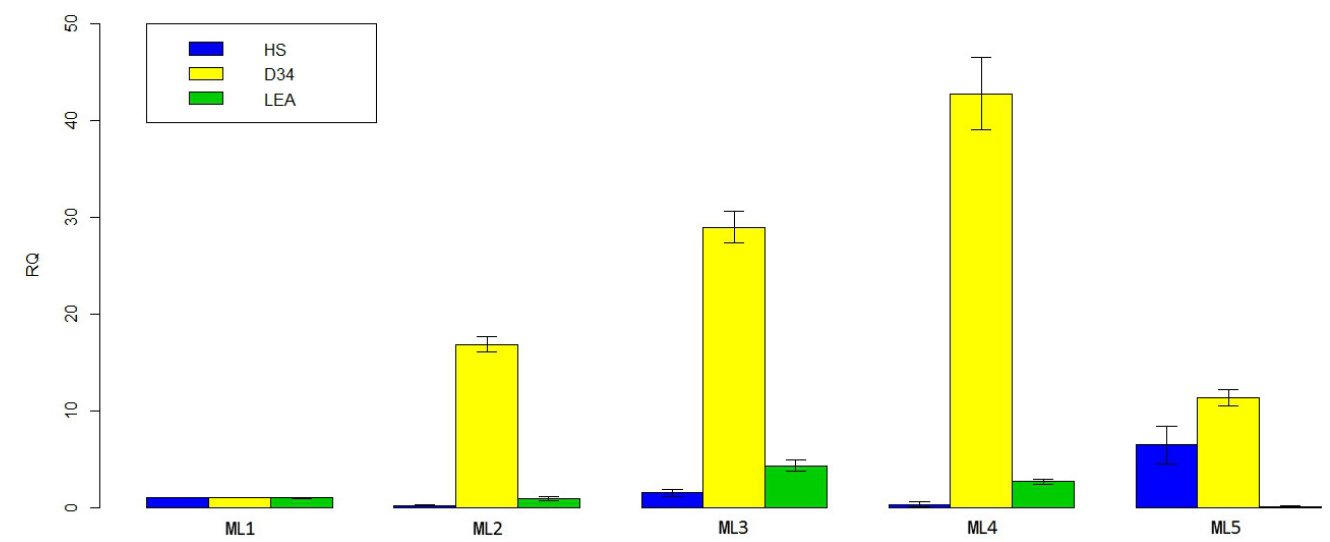

Figure 4. Profile of relative quantitative (RQ) expression of genes D34, HS, and LEA in maize seeds of line 91 collected at different stages of development.
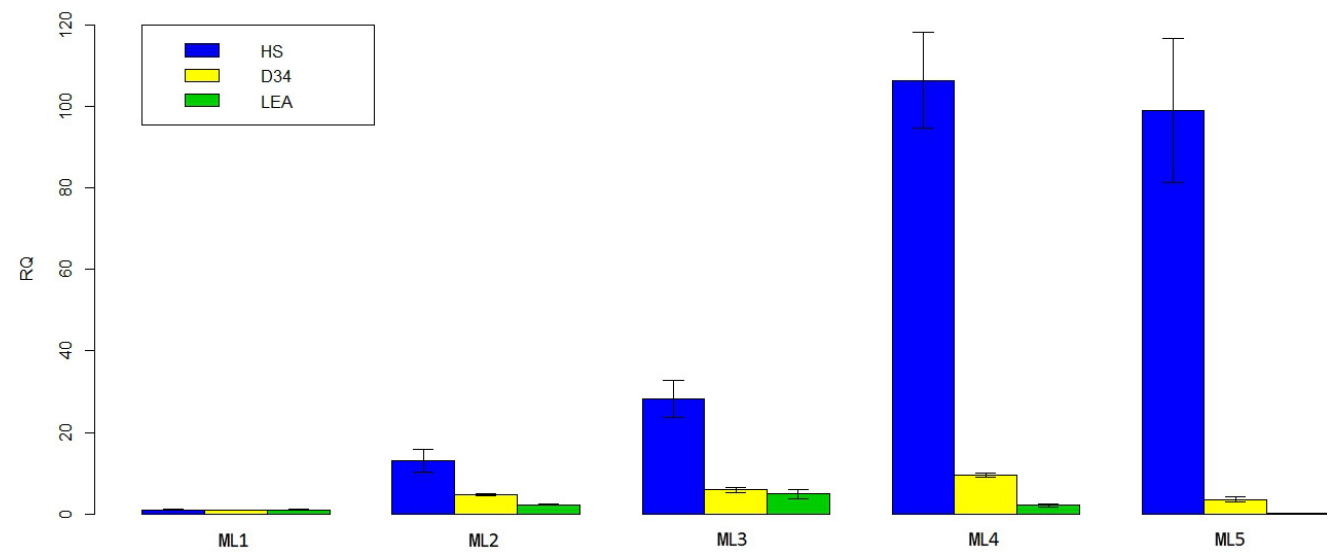

Figure 5. Profile of relative quantitative (RQ) expression of genes D34, HS, and LEA in maize seeds of line 57 collected at different stages of development.
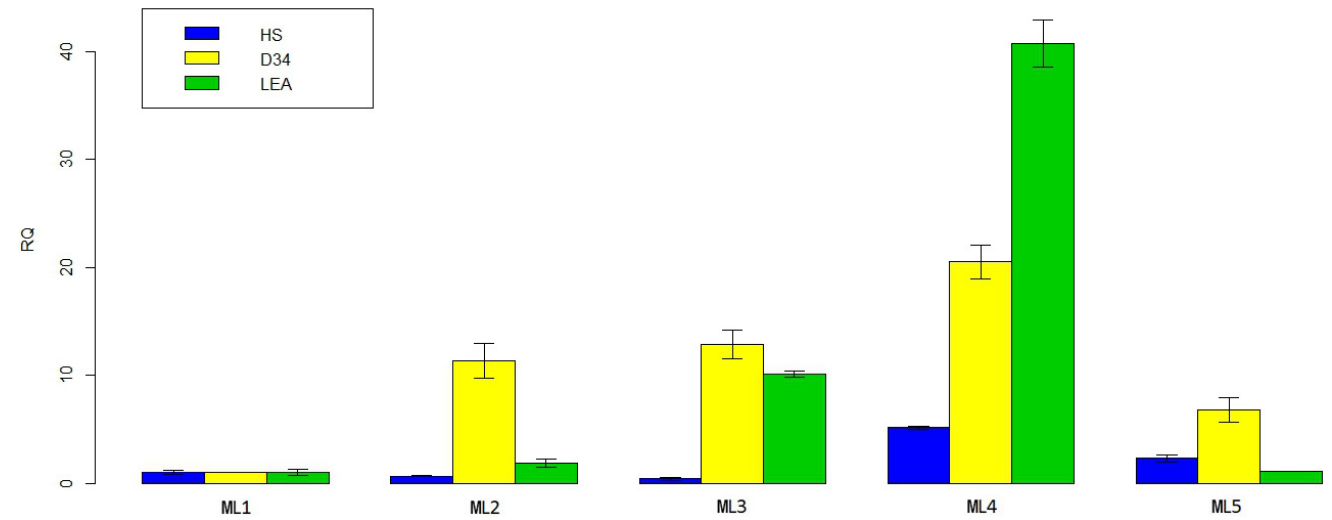

Figure 6. Profile of relative quantitative (RQ) expression of genes D34, HS, and LEA in maize seeds of line 30 collected at different stages of development. 
Expression of the HS gene in line 57 (Figure 5) seemed to be related to a $70-\mathrm{kDa}$ protein (Figure 1C), which also exhibited the greatest expression in the ML4 and ML5 stages of development.

In relation to gene $\mathrm{D} 34$, the greatest expression occurred in the seeds collected at the ML4 stage for most of the lines, with the highest relative levels occurring in the seeds of line 91 (Figure 4) and the lowest in the seeds of line 57 (Figure 5). For the seeds of line 91, the expression of gene D34 seemed to be related to a protein of approximately $70 \mathrm{kDa}$ (Figure 1D), which showed greatest expression in the ML4 stage of development.

Expression of the LEA gene was highest in the ML3 stage for seeds of lines 43, 91, and 57 (Figures 3, 4, and 5). Nevertheless, in line 30 (Figure 6), which had the highest relative expression compared to the other lines, greatest LEA expression occurred in the seeds collected at the ML5 stage.

\section{DISCUSSION}

In relation to physiological tests, it is possible that in the first count of germination in stages ML1 and ML2, the apparatus necessary for the germination process is not yet activated; therefore, normal seedlings were not observed in these stages (Table 3). It may also be observed that in the ML5 stage, the seeds of lines 30 and 43 had greater vigor than the others. Nevertheless, in the ML4 stage, greatest vigor was observed in seeds of line 91 . These results are in accordance with Gomes et al. (2000), who reported that physiological quality is affected by genotype. The comparison of these results with observed moisture content showed essentially no evidence of differences in moisture content of the seeds that might have explained differences in germination rates.

Roveri-José et al. (2004) studied germination in these same lines and observed high germination rates for lines 30 and 91 and lower rates for lines 43 and 57, where seeds had been collected at approximately $35 \%$ moisture content and dried artificially at $45^{\circ} \mathrm{C}$ to $11 \%$ moisture content.

Table 2 shows that the moisture content of the seeds of lines 30 and 57, in the ML5 stage of development, was less $(22.30 \%)$ and greater $(28.35 \%)$, respectively, in relation to the other lines. Roveri-José et al. (2005) observed that faster drying of the seeds was related to the structure of the pericarp, which may also happen in the field.

In general, germination tends to increase as moisture content decreases. This was observed by Faria et al. (2004), who concluded that natural water loss in the field prepares the seeds for germination when they are rehydrated.

In regard to vigor, evaluated by the accelerated aging test, Faria et al. (2004) also observed in seeds of other genotypes not subjected to drying that seeds collected at the ML5 stage had greater vigor than those collected at the other stages after artificial aging. Moreover, in the seeds collected at the ML3 stage, the authors found a greater percentage of normal seedlings after aging the seeds in relation to that seen in the germination test. According to Faria et al. (2004), the conditions in which the artificial aging test is performed (temperature of $42^{\circ} \mathrm{C}$ and high moisture) may favor leaching and reduce the abscisic acid content, exerting an effect on the seeds similar to natural drying, thereby promoting germination. Another hypothesis, according to the same authors, is that stress leads to the activation of enzymes, increasing the mobilization of reserves during germination. 
In the cold test, $83 \%$ vigor was observed in the seeds of line 91 collected at the ML2 stage. On the basis of this result, it is probable that the period in which the seeds remained saturated at low temperature favored the production of gibberellins and leaching of abscisic acid, factors that are directly involved in seed germination, since in the germination test only $3 \%$ of the seeds germinated (Table 4 ).

In general, greater germination and vigor values were observed in seeds collected at the ML5 stage of development. In line 91 seeds, greater germination and vigor values were observed in earlier stages of development (ML2 and ML3).

In relation to PCR expression by the electrophoresis technique, it may be observed from Figure 1 that for lines 91 and 30, there was greater expression in seeds collected in the earliest stages of development. In seeds collected in the ML5 stage of development, the difference in expression decreased. Thus, it may be inferred that in seeds of lines tolerant to desiccation, the expression of heat-resistant proteins occurs earlier. Skylas et al. (2002) found similar results while studying proteins associated with heat tolerance during grain filling in wheat, using high-resolution 2-D gel electrophoresis. Roveri-José et al. (2005), in evaluating the changes in the electrophoretic pattern of heat-resistant proteins in maize subjected to high drying temperature, concluded that it is not possible to determine a specific band of the fraction of heat-resistant proteins that may serve as a marker of tolerance to high drying temperature.

For line 91 (Figure 1D), a higher germination percentage was observed in seeds collected in earlier stages of development. Therefore, to correlate the expression of heat-resistant proteins to physiological quality, it is necessary to isolate this variable and inhibit the expression of other genes associated with physiological quality, such as amylase genes and other genes related to seed germination. Oliveira et al. (2013) studying amylase gene expression in maize seeds found great correlation between physiological quality and amylase gene expression, in which, high physiological quality genotypes showed more expression of amylase genes.

By means of the spectrophotometric technique, the lower expression of heat-resistant proteins was observed in seeds of lines 43 and 30, non-tolerant and tolerant, respectively. In the initial stages of development (ML1 and ML2), the seeds of line 57, showed highest levels of heat-resistant proteins. However, it is important to emphasize that other factors, in addition to heat-resistant proteins, also affect tolerance to desiccation. Roveri José et al. (2004) showed that the greatest tolerance to desiccation depends on the seed pericarp, a tissue of maternal origin.

In the results of expression of heat-resistant proteins assessed by the electrophoresis and spectrophotometry techniques, greater expression of these proteins was observed in the seeds collected in the final stage of development. Nevertheless, it is noteworthy that by the qRT-PCR technique, only 3 genes were assessed and quantified, and that by the electrophoretic and spectrophotometric techniques, the expression of more genes was analyzed. Probably, the genes that are expressed in more advanced stages of development were not studied in this research. Furthermore, it should be considered that there are different genes that code for LEA proteins. It is important to highlight the difference in expression of the genes studied in the different genotypes. Maestri et al. (2002) also observed genetic variability for heat tolerance and expression of individual heat shock proteins in cereal.

In seeds from line 91, in which greater expression of heat-resistant proteins was observed in earlier stages of development by the electrophoretic and spectrophotometric techniques, greater expression of the D34 gene was demonstrated, principally in the ML4 and ML5 stages of development. The expression pattern of this gene was similar to that observed 
in seeds of line 43, classified as having low tolerance to high drying temperatures.

Luo et al. (2008), upon evaluating the gene expression profile in development of maize seeds using the qRT-PCR technique, observed that the total number of transcripts decreased as the seeds matured; nevertheless, some proteins and enzymes may still remain active.

The expression of heat-resistant proteins evaluated by the electrophoretic and spectrophotometric techniques was greater in the more advanced stages of development, although there was differentiated expression of the genes studied in the different stages by the qRT-PCR technique. As previously discussed, the electrophoretic technique, in contrast to qRT-PCR, allows the assessment of the expression of various genes at the same time.

From the results obtained, it was observed that up to the ML3 stage of seed development, the expression of heat-resistant proteins was low. Thus, it may be inferred that, in this stage of development, the seeds do not exhibit the expression of these proteins that confer tolerance to high drying temperatures. Studies in which maize seeds were collected in the ML3 stage of development have recommended drying the seeds at $35^{\circ} \mathrm{C}$ until they reach around $25 \%$ moisture content, followed by drying at $45^{\circ} \mathrm{C}$. Faria et al. (2004) observed changes in the expression of heat-resistant proteins in seeds subjected to drying when compared to seeds not subjected to drying.

Therefore, seeds collected at less advanced stages of development do not seem to tolerate high drying temperatures since they do not exhibit the mechanisms responsible for tolerance to desiccation.

\section{CONCLUSIONS}

Heat-resistant proteins are expressed in a differential manner in seeds of different genotypes and at different stages of development. The expression of heat-resistant proteins as determined by electrophoresis is earlier in lines tolerant to high drying temperatures. There is greater germination and vigor in seeds collected at the ML5 stage of development.

\section{ACKNOWLEDGMENTS}

Research supported by Conselho Nacional de Desenvolvimento Científico e Tecnológico $(\mathrm{CNPq})$ and Fundação de Amparo à Pesquisa do Estado de Minas Gerais (FAPEMIG).

\section{REFERENCES}

ABRASEM - Associação Brasileira de Sementes e Mudas (2011). Anuário 2011. Brasília.

Bradford MM (1976). A rapid and sensitive method for the quantitation of microgram quantities of protein utilizing the principle of protein-dye binding. Anal. Biochem. 72: 248-254.

Brasil Ministério da Agricultura, Pecuária e Abastecimento (2009). Regras para Análise de Sementes. Ministério da Agricultura, Pecuária e Abastecimento. Secretaria de Defesa Agrocecuária, Brasília.

Dias MCL and Barros ASR (1995). Avaliação da Qualidade de Sementes de Milho. IAPAR, Londrina.

Faria MAVR, Von Pinho RG, Von Pinho EVR, Guimarães RM, et al. (2004). Germinabilidade e tolerância à dessecação em sementes de milho colhidas em diferentes estádios de maturação. Rev. Bras. Milho e Sorgo 3: 276-289.

Gomes MS, Von Pinho EVR, Von Pinho RG and Vieira MGGC (2000). Efeito da heterose na qualidade fisiológica de sementes de milho. Rev. Bras. Sementes 22: 7-17.

Huang H, Moller IM and Song SQ (2012). Proteomics of desiccation tolerance during development and germination of 
maize embryos. J. Proteomics 75: 1247-1262.

Hundertmark M and Hincha DK (2008). LEA (late embryogenesis abundant) proteins and their encoding genes in Arabidopsis thaliana. BMC Genomics 9: 118.

Hunter JL, Tekrony DM, Miles DF and Egli DB (1991). Corn seed maturity indicators and their relationship to uptake of carbon-14 assimilate. Crop Sci. 31: 1309-1313.

Luo M, Liu J, Lee RD and Guo BZ (2008). Characterization of gene expression profiles in developing kernels of maize (Zea mays) inbred Tex6. Plant Breed. 127: 569-578.

Maestri E, Klueva N, Perrotta C, Gulli M, et al. (2002). Molecular genetics of heat tolerance and heat shock proteins in cereals. Plant Mol. Biol. 48: 667-681.

Marcos Filho J (1994). Teste de Envelhecimento Acelerado. In: Testes de Vigor em Sementes (Vieira RD and Carvalho NM, eds.). FUNEP, Jaboticabal, 164.

Oliveira GE, Von Pinho RG, Andrade T, Von Pinho EVR, et al. (2013). Physiological quality and amylase enzyme expression in maize seeds. Ciênc. Agrotec. 37: 40-48.

R Development Core Team (2008). R: A Language and Environment for Statistical Computing. Available at [http:// www.R-project.org]. Accessed October 22, 2011. R Foundation for Statistical Computing, Vienna.

Roveri-José SCB, Von Pinho EVR, Von Pinho RG and Silveira CM (2004). Tolerância de sementes de linhagens de milho à alta temperatura de secagem. Ciênc. Agrotec. 28: 1107-1114.

Roveri-José SCB, Von Pinho EVR, Von Pinho RG and Silveira CM (2005). Padrão eletroforético de proteínas resistentes ao calor em sementes de milho. Pesq. Agropec. Bras. 40: 115-121.

Scholdberg TA, Norden TD, Nelson DD and Jenkins GR (2009). Evaluating precision and accuracy when quantifying different endogenous control reference genes in maize using real-time PCR. J. Agric. Food Chem. 57: 2903-2911.

Skylas DJ, Cordwell SJ, Hains PG, Larsen MR, et al. (2002). Heat shock of wheat during grain filling: Proteins associated with heat-tolerance. J. Cereal Sci. 35: 175-188. 